\title{
THE EFFECT OF CHAYOTE LEAVES (SECHIUM EDULE)'S FLAVONOID FRACTION ON THE REDUCTION OF THE SERUM URIC ACID LEVELS THROUGH THE INHIBITION OF XANTHINE OXIDASE ACTIVITY
}

\author{
Diah Pitaloka Putri, Aulia Putri Wahyuningtyas, Ahmad Ni'matullah Al-Baarri, Nani Maharani
}

\begin{abstract}
Uric acid is the final product of purine metabolism and is categorized as hyperuricemia when it reaches $>6.0 \mathrm{mg}^{\mathrm{d}} \mathrm{dL}^{-1}$ for women and $>7.0 \mathrm{mg} . \mathrm{dL}^{-1}$ for men. The chayote leaves (Sechium edule) contain a high amount of flavonoid and might be used as an alternative to reduce hyperuricemia. The purpose of this study is to analyze the effect of chayote leaves (Sechium edule)'s flavonoid fraction on the level of uric acid and the activity of xanthine oxidase (XO) in Sprague Dawley Rats. The flavonoid fraction (FF) was obtained by extracting the chayote leaves, fractionating with n-hexane, hydrolyzing with $\mathrm{HCl}$, and finally re-fractionating with ethyl acetate. Thirty male Sprague Dawley rats were induced for hyperuricemia by potassium oxonate and broth block for 21 days, and the interventions were given orally for 14 days. The rats were divided randomly into five groups: normal control (K-), hyperuricemia control (K+), hyperuricemia with FF dose $50 \mathrm{mg}^{2} 200 \mathrm{~g}^{-1}$ body weight

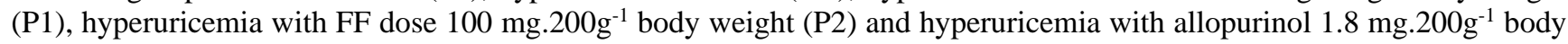
weight. Xanthine oxidase activity was measured by CheKine ${ }^{T M}$ Xanthine Oxidase Assay Kit, with simple colorimetry methods. The statistical analysis for XO activity was done using Kruskal-Wallis followed by Mann Whitney. The results showed that chayote leaves (Sechium edule)'s flavonoid fraction contains apigenin, apigenin o-glucoside, and luteolin. It also has antioxidant activity with $98.45 \%$ inhibition. There was a significant reduction in xanthine oxidase activity in groups treated with FF $(p<0.005)$. The best dose of FF affecting XO activity was $100 \mathrm{mg} .200 \mathrm{~g}^{-1}$ body weight. The combination of FF and allopurinol can be more effective in decreasing uric acid levels by inhibiting XO activity.
\end{abstract}

Keywords: flavonoids; Sechium edule; xanthine oxidase; uric acid

\section{INTRODUCTION}

Uric acid is the final product of purine metabolism, which is produced endogenously, and mostly comes from purines in foods consumed excessively. The uric acid level is high if it is more than $6.0 \mathrm{mg} . \mathrm{dL}^{-1}$ in women and more than 7.0 mg.dL ${ }^{-1}$ in men. An increase in uric acid levels is called hyperuricemia (Dalbeth et al., 2016; Kushiyama et al., 2016). The prevalence of hyperuricemia has increased rapidly in recent years, reaching $10 \%$ of the world's population. The increase in hyperuricemia does not merely occur in developed countries but also in developing countries (Kuo et al., 2015). Lifestyle factors include excessive purine diet (the habit of consuming seafood, internal meats such as liver, kidney, intestines), alcohol consumption, obesity, gender, and age, which are risk factors for increased hyperuricemia (Raja et al., 2019). Meanwhile, several other epidemiological studies have shown that hyperuricemia has an impact on the development of diabetes mellitus, dyslipidemia, kidney disease, obesity, hypertension, cardiovascular disease, and arthritis (Ma et al., 2019; Nurshad et al., 2018). Chayote is a type of vegetable that is widely found and consumed, especially in Mexico, Costa Rica, Guatemala, and Indonesia. The part of chayote that can be consumed apart from the fruit is its leaves. Chayote leaves have the potential as a source of nutrition and health benefits, such as hyperuricemia. However, chayote leaves are not as popular as the other part of the plant regardless of its content of bioactive compounds higher than the fruit. The bioactive compounds in chayote leaves include phenolics, carotenoids, and flavonoids (Managa et al., 2021; Siciliano et al., 2004). The flavonoids found in chayote leaves are apigenin and luteolin. The apigenin and luteolin content in chayote leaves is, respectively, $0.081{\mathrm{~g} .100 \mathrm{~g}^{-1}}^{-1}$

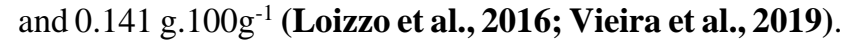
Flavonoids found in plants are often in demand due to their various bioactivity (Xiao, 2017). Currently, plants containing flavonoids are widely used as alternatives to help treat several diseases because the side effects are lower, and the price is relatively cheaper than drugs (Sahnoun and Saibi, 2018). Flavonoids have biological and pharmacological properties such as anti-oxidative, antibacterial, anti-viral, and anti-mutagenic. Flavonoids also play a role in reducing the activity of several enzymes, one 
of which is the xanthine oxidase enzyme (Lin et al., 2002). Xanthine oxidase is an enzyme responsible for catalyzing hypoxanthine and xanthine into uric acid, to control purine catabolism (Huang et al., 2011). Apigenin and luteolin have the effect of reducing uric acid levels by inhibiting the activity of the xanthine oxidase enzyme (Huang et al., 2011; Lin et al., 2018).

Another researcher indicates that administration of the flavonoid apigenin at a dose of $50 \mathrm{mg} .200 \mathrm{~g}^{-1}$ body weight and $100 \mathrm{mg} .200 \mathrm{~g}^{-1}$ body weight for seven days affects xanthine oxidase activity in both normal and hyperuricemia rats (Huang et al., 2011). Another report describes that luteolin is also a bioactive compound that plays a role in inhibiting the activity of the xanthine oxidase enzyme so that it affects the decrease in uric acid levels (Pauff and Hille, 2009).

\section{Scientific hypothesis}

Chayote leaves (Sechium edule)'s flavonoid fraction reduces serum uric acid levels through the inhibition of xanthine oxidase activity in Sprague Dawley rats hyperuricemia.

\section{MATERIAL AND METHODOLOGY}

This study was a true experimental research design using a randomized pre-post-test control group design. The study was conducted at the Animal Laboratory of PAU, Universitas Gadjah Mada, Yogyakarta for animal care, and Integrated Laboratory of Universitas Diponegoro, Semarang for the production of chayote leaves (Sechium edule)'s flavonoid fraction. This study had been approved by the Health Research Ethics Commission of the Faculty of Medicine, Universitas Diponegoro Semarang, with the number 05/EC/H/FK-UNDIP/I/2020.

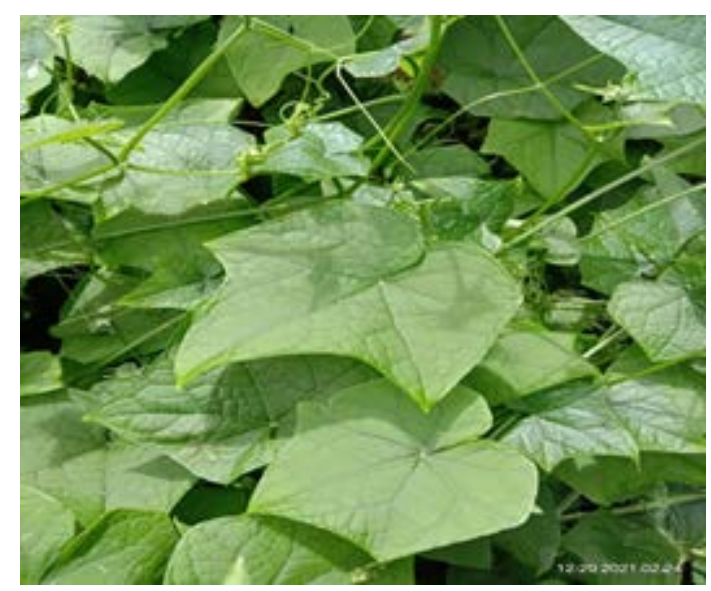

Figure 1 Chayote (Sechium edule) leaves.

\footnotetext{
Samples

The sample in this study used Rattus norvegicus, strain Sprague Dawley rats, weighing 150 - 300 g and aged 2 - 3 months.

Chemicals

Chemicals used in the fractionation of chayote leaves consisted of $\mathrm{HCl}$ (Merck 1.00317.2500, Germany), methanol (Brataco, Indonesia), ethyl-acetate, and n-hexane (Merck, Germany, packed by PT. Brataco, Indonesia). Chemicals of antioxidant activity test are methanol (Brataco, Indonesia), DPPH liquid (Sigma Aldrich,
}

Germany). Chemicals of XO activity test (assay buffer, sample diluent, WST-8, enhancer, and xanthine oxidase standard produced by Abbkine Scientific co., Ltd, Wuhan, China. Chemicals for uric acid levels test are uric acid reagent FS TBHBA (Diagnostic Systems GmbH, Germany).

\section{Animals and Biological Material}

Sprague dawley rats were obtained from Animal Laboratory of Universitas Gadjah Mada, Yogyakarta, Indonesia. The rats (except K-) induced with Maggi brand block broth (PT Nestle, Indonesia) at an amount of $140 \mathrm{mg} .200 \mathrm{~g}^{-1}$ rat's body weight and potassium oxonate (PO; Sigma Aldrich, USA) at a dose of $50 \mathrm{mg} .200 \mathrm{~g}^{-1}$ body weight for 21 days. Thirty rats were divided into five groups, namely the normal control group (K-) which received no induction and no treatment, the hyperuricemia control group $(\mathrm{K}+)$, the hyperuricemia group with the administration of FF from chayote leaves at a dose of $50 \mathrm{mg}^{2} 20 \mathrm{gg}^{-1}$ body weight (P1), the hyperuricemia group which was administered FF from chayote leaves at a dose

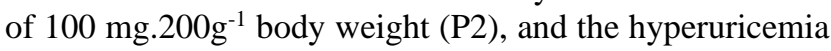
group which was given allopurinol at the dose of $1.8 \mathrm{mg} .200 \mathrm{~g}^{-1}$ body weight (P3). The rats were given oral intervention (FF) for 14 days. The FF was obtained by the fractionation method from chayote leaves (Sechium edule). The criteria of chayotes were fresh leaves with no hollow or mold, and leaves were $>28$ days old. The chayote leaves were obtained from chayote farm in Ngablak, Magelang, Central Java, Indonesia.

\section{Instruments}

iMark $^{\mathrm{TM}}$ microplate absorbance reader, BioRad.Microprocessor Controlled Spectrophotometer, (OPTIMA SP-300, Japan) for reader absorbance of uric acid levels and XO activity; Shimadzu UV-1800 UV-Vis Spectrophotometer (Japan) for reader absorbance of antioxidant activity by DPPH method.

\section{Laboratory Methods}

Before and after the intervention (2 times), the blood tests were carried out to measure the serum uric acid level and XO activity. The uric acid level was measured using the enzymatic method using the uric acid reagent FS TBHBA (2,4,6-tribromo 3 hydroxybenzoic acid), while the XO activity was measured using the CheKine ${ }^{T M}$ Xanthine Oxidase Assay Kit with a colorimetric test method. The antioxidant activity was measured by the DPPH method. DPPH method's principle is the sample's ability to reduce the oxidation process of DPPH free radicals (1,1-diphenyl2-picrylhydrazyl) in methanol solution.

\section{Description of the Experiment}

Sample preparation: After 14 days of intervention, blood was collected from the sinus orbital $( \pm 2 \mathrm{~mL})$ and centrifuged at $1,000 \mathrm{rpm}$ for 15 minutes at $2-8{ }^{\circ} \mathrm{C}$, plasma was collected and stored at $-80{ }^{\circ} \mathrm{C}$ for later analysis. The analytical procedures were done according to the instruction of the kits. Thirty samples were analyzed, and each sample was measured twice (duplicate). Each treatment group consisted of six rats.

\section{Statistical Analysis}

The results are presented as median (min-max) data. The difference in XO activity was tested using Kruskal Wallis (nonparametric) test followed by Mann-Whitney post-hoc test. The differences were considered significant at a 
$p$-value $<0.005$. The SPSS software version 21 (SPSS Inc, Chicago, IL, USA) was used to perform the tests.

\section{RESULTS AND DISCUSSION}

In this study, the antioxidant activity of chayote's flavonoid fraction was measured prior to the start of the experiment. Antioxidant activity from the flavonoid fraction of chayote (Sechium edule) leaves has a stronger ability to ward off free radicals than allopurinol (Table 1). High or low ability to reduce free radicals can be seen from the amount of percent inhibition. The higher percent of inhibition shows more materials to reduce free radicals. In contrast, a lower percent of inhibition shows less material to reduce free radicals. The inhibition process is thought to occur when the DPPH radical reacts with antioxidant compounds through the uptake of hydrogen ions. Flavonoids have a hydroxyl group $(\mathrm{OH})$ so that the flavonoid can ward off free radicals by donating hydrogen and change free radicals from unstable to more stable (Sangeetha et al., 2016).

Rats were weighed every week, starting at the time of acclimatization, during the intervention, and after the completion of the intervention. Weighing the rats aimed to monitor weight gain and determine the initial dose of flavonoid fractions and allopurinol. The results of body weight measurements showed an increase during the study (data not shown). In hyperuricemia groups, the increase in body weight is higher than in the control group. Different metabolic responses to different treatments might cause the difference in rats' weight gains.

Serum uric acid level measurement showed a decrease after treatment in P1 and P2 (flavonoid fraction) and P3 (allopurinol) groups, as shown in Table 2. In contrast, the $\mathrm{K}$ - and $\mathrm{K}+$ groups (the control group) experienced an increase in uric acid, as shown in Table 1 . The most significant decrease in serum uric acid level was found in the allopurinol group. Thus, allopurinol administration was proven to be more effective in reducing uric acid levels than flavonoid fractions at either dose. Among the flavonoidtreated group, the one gave $100 \mathrm{mg}^{2} 20 \mathrm{~g}^{-1} \mathrm{BW}$ flavonoid showed a better reduction than the lower one, indicating that the flavonoid fraction's effect is dose-dependent.

Based on the results of this study, it is observed that the chayote leaves (Sechium edule)'s flavonoid fraction affects the reduction of uric acid levels in rats for 14 days. The research found out that the administration of a fraction of the breadfruit leaves affects decreasing blood uric acid levels in rats (Sinata, 2019). Research on human samples proved that administering Sechium edule extract three times a day for six weeks can reduce uric acid levels in subjects with metabolic syndrome disease (Rosado-Pérez et al., 2019). The result of previous studies reported that intervention using allopurinol was more effective in decreasing uric acid levels compared to flavonoids from plants, but the side effects were more dangerous (Jiang et al., 2020; Harwoko and Warsinah, 2020; Abdulhafiz et al., 2020). Chayote leaves (Sechium edule)'s flavonoid fraction and allopurinol have the same effect on reducing blood uric acid levels. Still, allopurinol has more side effects, including fever, skin rashes, allergies, hepatitis, kidney disease, and the risk of cardiovascular diseases (Shah and Shah, 2015; Presa et al., 2019; Stamp et al., 2011; Bove et al., 2017).

The XO activity measurements were undertaken twice, before and after the intervention. The results showed that the treatment groups experienced a decrease, and the control group showed an increase in XO activity. The reduction in $\mathrm{XO}$ activity was shown by the groups given treatment, the P1 (flavonoid fraction $50 \mathrm{mg}^{2} 200 \mathrm{~g}^{-1} \mathrm{BW}$ ), P2 (flavonoid fraction $100 \mathrm{mg}^{2} 200 \mathrm{~g}^{-1} \mathrm{BW}$ ), and P3 (allopurinol $\left.1.8 \mathrm{mg} .200 \mathrm{~g}^{-1} \mathrm{BW}\right)$. This reduction in XO activity reflected the inhibition of uric acid formation.

Table 1 Antioxidant Activity (percent inhibition).

\begin{tabular}{ccc} 
Methods & Materials & \% inhibition \\
\multirow{2}{*}{ DPPH } & Chayote leaves (Sechium edule)'s & 91.45 \\
& flavonoid fraction & Allopurinol \\
\hline
\end{tabular}

Table 2 Statistical Analysis of Xanthine Oxidase Activity.

\begin{tabular}{lccccc}
\hline $\begin{array}{c}\text { Xanthine } \\
\text { Oxidase } \\
\begin{array}{c}\text { Activity } \\
(\%)\end{array}\end{array}$ & K- & \multicolumn{5}{c}{ Groups } \\
\cline { 2 - 6 } & 29.53 & $\mathbf{K}+$ & $\mathbf{P 1}$ & $\mathbf{P 2}$ & $\mathbf{P 3}$ \\
\hline Pre & $(27.54-31.79)$ & $(67.86-71.43)$ & $(68.09-70.41)$ & $(67.11-9.58)$ & $(65.87-69.07)$ \\
& 30.70 & 70.12 & 51.85 & 37.10 & 32.74 \\
Post & $(29.32-32.69)$ & $(68.95-71.69)$ & $(46.99-55.32)$ & $(34.14-40.13)$ & $(32.00-35.14)$ \\
& 0.028 & 0.028 & 0.028 & 0.028 & 0.028 \\
$p^{1}$ & 1.36 & 0.93 & 17.37 & -32.10 & -35.79 \\
$\triangle$ & $(0.64-1.78)$ & $(0.28-2.04)$ & $(-23.42--14.49)$ & $(-34.68--26.98)$ & $(-36.37--30.73)$ \\
$p^{2}$ & & & 0.000 & & \\
\hline
\end{tabular}

Note : Five groups of rats consisted of K-: normal rats; K+: hyperuricemia rats; P1:flavonoid fraction from chayote leaves (Sechium edule) treatment at dose $50 \mathrm{mg} .200 \mathrm{~g}^{-1}$ bodyweight; P2: flavonoid fraction from chayote leaves (Sechium edule) treatment at dose $100 \mathrm{mg} .200 \mathrm{~g}^{-1}$ bodyweight; P3: allopurinol treatment at dose $1.8 \mathrm{mg} .200 \mathrm{~g}^{-1}$ bodyweight; $p^{1}: p$ values were obtained by Wilcoxon test between pre and post intervention; $p^{2}: p$ values were obtained by Kruskal Wallis test (all groups); $\triangle$ : changes between pre and post treatment. The results are presented as median (min-max) for not normally distributed data. 


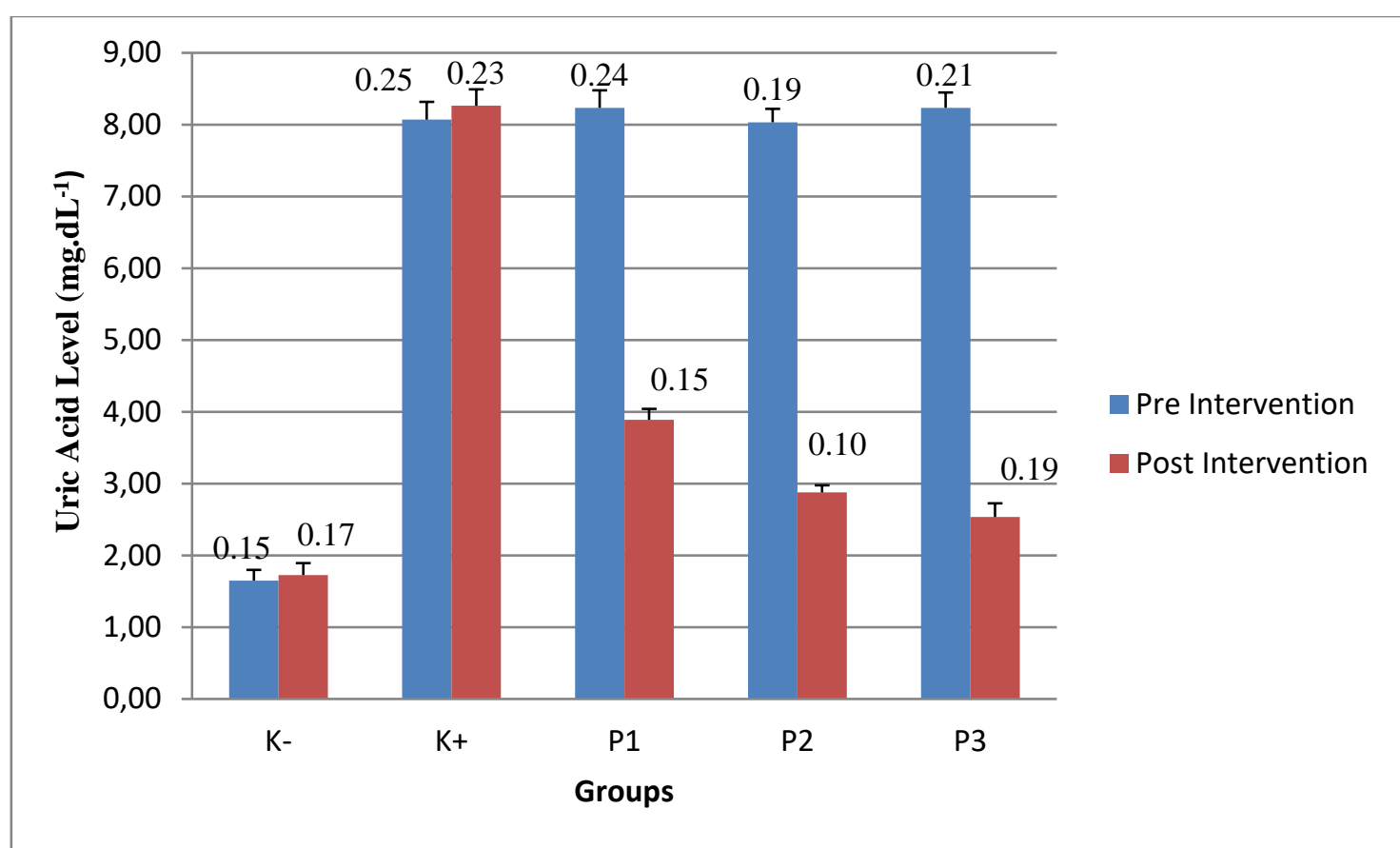

Figure 2 Changes of uric acid level (pre and post intervention chayote leaves (Sechium edule)'s flavonoid fraction.

The average ability of the flavonoid fractions from chayote leaves to reduce XO activity was $18.19 \%$ and $31.46 \%$ for $\mathrm{P} 1$ and P2, respectively, while the P3 (allopurinol group) showed a $40.95 \%$ reduction.

In the groups without any treatment, $\mathrm{XO}$ activity increased, with the largest increase was shown by the K- group (1.25\%). An increase in xanthine oxidase activity indicated the formation of serum uric acid.

The Wilcoxon test results showed that the XO activity before and after the intervention was significantly different ( $p=0.028$ ) (Table 2). XO activity tended to increase in the control group, while in the treatment group, $\mathrm{XO}$ activity decreased. The results showed that flavonoid fraction intervention for 14 days affected the decrease of XO activity in hyperuricemic rats. The results of the Kruskal-Wallis test in this study showed that there were differences in $\mathrm{XO}$ activity after intervention in all groups $(p=0.000)$ (Table $2)$. In the control group, $\mathrm{XO}$ activity tended to increase, while in the treatment group, XO activity decreased. This result showed that the intervention of flavonoid fraction for 14 days affected the decrease of xanthine oxidase activity in hyperuricemic rats.

In this study, the highest decrease in XO activity in the treatment group occurred from chayote leaves at the dose of 100 mg.200g ${ }^{-1}$ BW. However, allopurinol administration was proven to be more effective in reducing the highest $\mathrm{XO}$ activity than the chayote leaves (Sechium edule)'s flavonoid fraction at a dose of 100/200 mg.g $\mathrm{g}^{-1} \mathrm{BW}$ and 50/200 mg.g ${ }^{-1}$ BW. The decrease in uric acid levels in the treatment groups, P1 and P2, was probably due to the content of bioactive compounds in the flavonoid fraction, which can inhibit the activity of the XO enzyme so that uric acid was not formed. The results of previous studies in vitro and in vivo reported that flavonoids contribute to antihyperuricemic activity by inhibiting XO activity (Mohos et al., 2020; Yunita, Santoso and Subandi, 2021).

Xanthine oxidase is an enzyme that contributes to the production of uric acid by catalyzing hypoxanthine to xanthine and xanthine to uric acid in purine metabolism. These higher uric acid concentrations are in response to higher levels of XO activity and oxidative stress. Previous research reported that Cudrania tricuspidata leaf extract with high flavonoids administered to rats could inhibit XO activity (Song et al., 2018). The flavonoid content of plants has antioxidant properties, which could suppress the XO enzyme so that more hypoxanthine and xanthine are excreted in the urine. The formation of uric acid can be inhibited, shown by the lower level in the blood (Casagrande et al., 2013; Serrano et al., 2020). Other research shows that flavonoids extract from Marantodes Pumilum var pumila leaves can decrease XO activity in hyperuricemia mice (Aladdin et al., 2020).

The decrease in uric acid levels is due to flavonoids content in this plant, which has a very good effect on XO activity, inhibits purine biosynthesis in the body (Zeng et al., 2017), and increases the concentration of uric acid in the urine (Kuo et al., 2015; Ling and Bochu, 2014; Shi and Williamson, 2016). Another mechanism by which the flavonoids reduce serum uric acid level is inhibition of uric acid reabsorption in the kidney (Hamada et al., 2008). The bioactive compounds in plants reduce the expression of mRNA and protein transporter URAT1 and GLUT9 in hyperuricemic rats, associated with uricosuric effects with inhibition of uric acid reabsorption (Hu et al., 2012; Yang et al., 2015; Dolati et al., 2018).

Based on the results of this study, the flavonoid fraction (apigenin and luteolin) can affect XO activity. In addition, the results of the FTIR test showed that the flavonoid fraction from chayote leaves contains the structure of $\mathrm{C} 2$, which has an effect of reducing XO activity. Previous research reported that the basic chemical structure of the flavanol group with $\mathrm{C} 2$ and $\mathrm{C} 3$ double bonds in the flavonoid compound was found to be very influential in the inhibition of high XO activity (Van Hoorn et al., 2002; Spanou et al., 2012). 


\section{CONCLUSION}

Chayote leaves (Sechium edule) contain flavonoids (apigenin and luteolin), which affected serum uric acid levels in the hyperuricemic rat model after 14 days of treatment; however, its effect was lower than those of allopurinol. This reduction was due to the inhibition of XO activity, and the best result of this flavonoid fraction was observed at $100 \mathrm{mg}^{2} 20 \mathrm{~g}^{-1}$ BW. Combining FF or flavonoids from plants and allopurinol can be more effective to decrease uric acid levels through the inhibition of XO activity. This finding might be useful to be implemented in humans to improve hyperuricemia conditions.

\section{REFERENCES}

Abdulhafiz, F., Mohammed, A., Kayat, F., Bhaskar, M., Hamzah, Z., Podapati, S. K., Reddy, L. V. 2020. Xanthine oxidase inhibitory activity, chemical composition, antioxidant properties and GC-MS analysis of keladi candik (Alocasia longiloba Miq). Molecules, vol. 25, no. 11, p. 2658. https://doi.org/10.3390/molecules25112658

Aladdin, N. A., Husain, K., Jalil, J., Sabandar, C. W., Jamal, J. A. 2020. Xanthine oxidase inhibitory activity of a new isocoumarin obtained from Marantodes pumilum var. pumila leaves. BMC Complementary Medicine and Therapies, vol. 20, no. 1, p. 1-12. https:/doi.org/10.1186/s12906-020-03119-8

Bove, M., Cicero, A. F. G., Veronesi, M., Borghi, C. 2017. An evidence-based review on urate-lowering treatments: Implications for optimal treatment of chronic hyperuricemia. Vascular Health and Risk Management, vol. 13, p. 23-28. https://doi.org/10.2147/VHRM.S115080

Casagrande, A. C. M., Wamser, M. N., De Lima, D. D., Da Cruz, J. G. P., Wyse, A. T. S., Dal Magro, D. D. 2013. In vitro stimulation of oxidative stress by hypoxanthine in blood of rats: Prevention by vitamins e plus $\mathrm{C}$ and allopurinol. Nucleosides, Nucleotides and Nucleic Acids, vol. 32, no. 1, p. 42-57. https://doi.org/10.1080/15257770.2012.760043

Dalbeth, N., Merriman, T., Stamp, L. 2016. Gout. The Lancet, vol. 388, no. 10055, p. 2039-2052. https://doi.org/10.1016/S0140-6736(16)00346-9

Dolati, K., Rakhshandeh, H., Golestani, M., Forouzanfar, F., Sadeghnia, R., Sadeghnia, H. 2018. Inhibitory effects of apium graveolens on xanthine oxidase activity and serum Uric acid levels in hyperuricemic mice. Preventive Nutrition and Food Science, vol. 23, no. 2, p. 127-133. http://doi.org/10.3746/pnf.2018.23.2.127

Hamada, T., Ichida, K., Hosoyamada, M., Mizuta, E., Yanagihara, K., Sonoyama, K., Sugihara, S., Igawa, O., Hosoya, T., Ohtahara, A., Shigamasa, C., Yamamoto, Y., Ninomiya, H., Hisatome, I. 2008. Uricosuric action of losartan via the inhibition of urate transporter 1 (URAT 1) in hypertensive patients. American Journal of Hypertension, vol. 21, no. 10, p. 1157-1162. https://doi.org/10.1038/ajh.2008.245

Harwoko, H., Warsinah, W. 2020. Phytochemical analysis and evaluation of purified extract of Tinospora crispa stem for in vivo antihyperuricemic. Journal of Reports in Pharmaceutical Sciences, vol. 9, no. 1, p. 46-51. https://doi.org/10.4103/jrptps.JRPTPS_45_19

Hu, Q. H., Zhang, X., Wang, X., Jiao, R. Q., Kong, L. D. 2012. Quercetin regulates organic ion transporter and uromodulin expression and improves renal function in hyperuricemic mice. European Journal of Nutrition, vol. 51, no. 5, p. 593-606. https://doi.org/10.1007/s00394-011-0243-y

Huang, J., Wang, S., Zhu, M., Chen, J., Zhu, X. 2011. Effects of genistein, apigenin, quercetin, rutin and astilbin on serum uric acid levels and xanthine oxidase activities in normal and hyperuricemic mice. Food and Chemical Toxicology, vol. 49, no. 9, p. 1943-1947. https://doi.org/10.1016/j.fct.2011.04.029

Jiang, L. L., Gong, X., Ji, M. Y., Wang, C. C., Wang, J. H., Li, M. H. 2020. Bioactive compounds from plant-based functional foods: A promising choice for the prevention and management of hyperuricemia. Foods, vol. 9, no. 8, p. 973. https://doi.org/10.3390/foods9080973

Kuo, C. F., Grainge, M. J., Zhang, W., Doherty, M. 2015. Global epidemiology of gout: Prevalence, incidence and risk factors. Nature Reviews Rheumatology, vol. 11, no. 11, p. 649662. https://doi.org/10.1038/nrrheum.2015.91

Kushiyama, A., Nakatsu, Y., Matsunaga, Y., Yamamotoya, T., Mori, K., Ueda, K., Inoue, Y., Sakoda, H., Fujishiro, M., Ono, H., Asano, T. 2016. Role of uric acid metabolism-related inflammation in the pathogenesis of metabolic syndrome components such as atherosclerosis and nonalcoholic steatohepatitis. Mediators of Inflammation, vol. 2016, p. 1-15. https://doi.org/10.1155/2016/8603164

Lin, C. M., Chen, C. S., Che, T. S., Liang, Y. C. 2002. Molecular modeling of flavonoids that inhibits xanthine oxidase. Biochemical and Biophysical Research Communication, vol. 294, p. 167-172. http://doi.org/10.1016/S0006-291X(02)00442-4

Lin, Y., Liu, P. G., Liang, W. Q., Hu, Y. J., Xu, P., Zhou, J., Pu, J. B., Zhang, H. J. 2018. Luteolin-4'-O-glucoside and its aglycone, two major flavones of Gnaphalium affine D. Don, resist hyperuricemia and acute gouty arthritis activity in animal models. Phytomedicine, vol. 41, p. 54-61. https://doi.org/10.1016/j.phymed.2018.02.002

Ling, X., Bochu, W. 2014. A review of phytotherapy of gout: Perspective of new pharmacological treatments. Pharmazie, vol. 69, no. 4, p. 243-256. https://doi.org/10.1691/ph.2014.3642

Loizzo, M. R., Bonesi, M., Menichini, F., Tenuta, M. C., Leporini, M., Tundis, R. 2016. Antioxidant and carbohydratehydrolysing enzymes potential of Sechium edule (Jacq.) Swartz (Cucurbitaceae) Peel, leaves and Pulp fresh and processed. Plant Foods for Human Nutrition, vol. 71, no. 4, p. 381-387. https://doi.org/10.1007/s11130-016-0571-4

Ma, Z., Wang, Y., Xu, C., Ai, F., Huang, L., Wang, J., Peng, J., Zhou, Y., Yin, M., Zhang, S., Yang, X. 2019. Obesityrelated genetic variants and hyperuricemia risk in Chinese men. Frontiers in Endocrinology, vol. 10, 18 p. https://doi.org/10.3389/fendo.2019.00230

Managa, M. G., Akinola, S. A., Remize, F., Garcia, C., Sivakumar, D. 2021. Physicochemical Parameters and Bioaccessibility of Lactic Acid Bacteria Fermented Chayote Leaf (Sechium edule) and Pineapple (Ananas comosus) Smoothies. Front Nutr., vol. 8, p. 649189. https://doi.org/10.3389\%2Ffnut.2021.649189

Mohos, V., Fliszár-Nyúl, E., Poór, M. 2020. Inhibition of xanthine oxidase-catalyzed xanthine and 6-mercaptopurine oxidation by flavonoid aglycones and some of their conjugates. International Journal of Molecular Sciences, vol. 21, no. 9, p. 3256. https://doi.org/10.3390/ijms21093256

Nurshad, A., Perveen, R., Shahnaz, R., Shakil, M., Sadaqur, R., Shiful, I., Tangigul, H., Abu Hasan, S., Rahanuma, R. K., Noyan, H. M., Farjan, I., Nayan, C. M., Shaikh, M. N., Shamim, A., Mustafizur, R. 2018. Prevalence of hyperuricemia and the relationship between serum uric acid and obesity: A study on Bangladeshi adults. Plos One, vol. 13, no. 11, p. e0206850. https://doi.org/10.1371/journal.pone.0206850

Pauff, J. M., Hille, R. 2009. Inhibition studies of bovine xanthine oxidase by luteolin, silibhinin, quercetin and 
curcumin. J Nut Food, vol. 72, no. 4, p. 725-731. https://doi.org/10.1021/np8007123

Presa, M., Pérez-Ruiz, F., Oyagüez, I. 2019. Second-line treatment with lesinurad and allopurinol versus febuxostat for management of hyperuricemia: a cost-effectiveness analysis for Spanish patients. Clinical Rheumatology, vol. 38, no. 12, p. 3521-3528. https://doi.org/10.1007/s10067-019-04739-3

Raja, S., Kumar, A., Aahooja, R. D., Thakuria, U., Ochani, S., Shaukat, F. 2019. Frequency of hyperuricemia and its risk factors in the adult population. Cureus, vol. 6, no. 11, p. e4198 https://doi.org/10.7759/cureus.4198

Rosado-Pérez, J., Aguiñiga-Sánchez, I., Santiago-Osorio, E., Mendoza-Núñez, V. 2019. Effect of Sechium edule var. nigrum spinosum (Chayote) on Oxidative stress and pro-inflammatory markers in older adults with metabolic syndrome: an exploratory study. Antioxidants, vol. 8, no. 5, p. 146. https://doi.org/10.3390/antiox8050146

Sahnoun, M., Saibi, W. 2018. Apigenin isolated from A . americana encodes Human and Aspergillus oryzae S2 a amylase inhibitions: credible approach for antifungal and antidiabetic therapies. Journal Food Science Technology. https://doi.org/10.1007/s13197-018-3065-6

Sangeetha, K., Umamaheswari, K. S., Reddy, M., Kalkura, S. N. 2016. Flavonoids Therapeutic potential of natural pharmacological agents. International Journal of Pharmaceutical Sciences and Research, vol. 7, no. 10, p. 3924. https://doi.org/10.13040/IJPSR.0975-8232.7(10).3924-30

Serrano, J. L., Figueiredo, J., Almeida, P., Silvestre, S. 2020. From Xanthine Oxidase Inhibition to in vivo hypouricemic effect: an integrated overview of in vitro and in vivo studies with focus on natural molecules and analogues. EvidenceBased Complementary and Alternative Medicine, vol. 2020, p. 9-11. https://doi.org/10.1155/2020/9531725

Shah, P., Shah, G. 2015. Uricosuric activity of Tinospora cordifolia. Bangladesh Journal of Pharmacology, vol. 10, no. 4, p. 884-890. https://doi.org/10.3329/bjp.v10i4.25160

Shi, Y., Williamson, G. 2016. Quercetin lowers plasma uric acid in pre-hyperuricaemic males: A randomised, doubleblinded, placebo-controlled, cross-over trial. British Journal of Nutrition, vol. 115, no. 5, p. 800-806. https://doi.org/10.1017/S0007114515005310

Siciliano, T., De Tommasi, N., Morelli, I., Braca, A. 2004. Study of flavonoids of Sechium edule (Jacq) Swartz (Cucurbitaceae) different edible organs by liquid chromatography photodiode array mass spectrometry. Journal of Agricultural and Food Chemistry, vol. 52, no. 21, p. 6510-6515. https://doi.org/10.1021/jf040214q.

Sinata, N. 2019. Aktivitas etil asetat Artocarpus altilis (Parkinson Ex F.A.Zorn) fosberg terhadap kadar asam urat mencit putih jantan hiperurisemia (Ethyl acetate activity of Artocarpus altilis (parkinson ex f.a.zorn) fosberg on uric acid levels of hyperuricemic male rats). Jurnal Ilmiah Farmasi Farmasyifa (Scientific Journal of Farmasyifa Pharmacy), vol. 2, no. 2, p. 93-100. https://doi.org/10.29313/jiff.v2i2.4795 (In Indonesia)

Song, S. H., Park, D. H., Bae, M. S., Choi, C. Y., Shim, J. H., Yoon, G., Cho, Y. C., Oh, D. S., Yoon, I. S., Cho, S. S. 2018. Ethanol extract of cudrania tricuspidata leaf ameliorates hyperuricemia in Mice via inhibition of hepatic and serum xanthine oxidase activity. Evidence-Based Complementary and Alternative Medicine, vol. 2018, p. 1-9. https://doi.org/10.1155/2018/8037925

Spanou, C., Veskoukis, A., Kerasioti, T., Kontou, M., Angelis, A., Aligiannis, N., Skaltsounis, A., Kouretas, D. 2012. Flavonoid glycosides isolated from unique legume plant extracts as novel inhibitors of xanthine oxidase. PLOS ONE, $\begin{array}{lcccc}\text { vol. } & 7, & \text { no. } & 3, & \text { p. } \\ \text { https://doi.org/10.1371/journal.pone.0032214 }\end{array}$

e32214.

Stamp, L. K., O’Donnell, J. L., Zhang, M., James, J., Frampton, C., Barclay, M. L., Chapman, P. T. 2011. Using allopurinol above the dose based on creatinine clearance is effective and safe in patients with chronic gout, including those with renal impairment. Arthritis and Rheumatism, vol. 63, no. 2, p. 412-421. https://doi.org/10.1002/art.30119

Van Hoorn, D. E. C., Nijveldt, R. J., Van Leeuwen, P. A. M., Hofman, Z., M’Rabet, L., De Bont, D. B. A., Van Norren, K. 2002. Accurate prediction of xanthine oxidase inhibition based on the structure of flavonoids. European Journal of Pharmacology, vol. 451, no. 2, p. 111-118. https://doi.org/10.1016/S0014-2999(02)02192-1

Vieira, E. F., Pinho, O., Ferreira, I. M. P. L. V. O., DelerueMatos, C. 2019. Chayote (Sechium edule): A review of nutritional composition, bioactivities and potential applications. Food Chemistry, vol. 275, p. 557-568. https://doi.org/10.1016/j.foodchem.2018.09.146

Xiao, J. 2017. Dietary flavonoid aglycones and their glycosides: Which show better biological significance? Critical Reviews in Food Science and Nutrition, vol. 57, no. 9, p.

1874-1905.

https://doi.org/10.1080/10408398.2015.1032400

Yang, H., Gao, L., Niu, Y., Zhou, Y., Jiang, J., Kong, X., Liu, X., Li, L. 2015. Mangiferin inhibits renal urate reabsorption by modulating urate transporters in experimental hyperuricemia. Biological and Pharmaceutical Bulletin, vol. 38, no. 10, p. 1591-1598. https://doi.org/10.1248/bpb.b15-00402

Yunita, Y., Santoso, A., Subandi, S. 2021. Xanthine oxidase inhibitory activity and identification of flavonoid in ethanol extract of sugar apple fruit (Annona squamosa L.). AIP Conference Proceedings, vol. 2353, p. 030068. https://doi.org/10.1063/5.0052695

Zeng, Y. C., Li, S., Liu, C., Gong, T., Sun, X., Fu, Y., Zhang, Z. R. 2017. Soluplus micelles for improving the oral bioavailability of scopoletin and their hypouricemic effect in vivo. Acta Pharmacologica Sinica, vol. 38, no. 3, p. 424-433. https://doi.org/10.1038/aps.2016.126

\section{Funds:}

This research did not receive any specific grant from funding agencies in the public, commercial, or not-forprofit sectors.

\section{Acknowledgments:}

The authors are grateful to Nurul Yaqin from Laboratorium Terpadu Universitas Diponegoro Semarang for his help in preparing the chayote leaves (Sechium edule)'s flavonoid fraction, and to Dr. Yuliyanto from PAU Gadjah Mada University for his assistance in animal model preparation

\section{Conflict of Interest:}

The authors declare no conflict of interest.

\section{Ethical Statement:}

This research was approved by the Ethics Committee of the Health Research Diponegoro University, Indonesia following the legislation of the number $05 / \mathrm{EC} / \mathrm{H} / \mathrm{FK}$ UNDIP/1/2020 on the June $18^{\text {th }}, 2020$. 


\section{Potravinarstvo Slovak J ournal of Food Sciences}

\section{Contact Address:}

Diah Pitaloka Putri, Universitas Diponegoro, Faculty of Medicine, Department of Nutrition, Tembalang Semarang Indonesia, 50275,

E-mail: diahpitalokaputri8@gmail.com

ORCID: https://orcid.org/0000-0002-4053-6200

Aulia Putri Wahyuningtyas, Universitas Diponegoro, Faculty of Medicine, Department of Nutrition, Tembalang Semarang Indonesia, 50275,

E-mail: putrityas221@gmail.com

ORCID: https://orcid.org/0000-0002-1389-7772
Ahmad Ni’matullah Al-Baarri, Universitas Diponegoro, Faculty of Animal and Agricultural Sciences, Department of Food Technology, Tembalang Semarang Indonesia 50275,

E-mail: albari@live.undip.ac.id

ORCID: https://orcid.org/0000-0002-1459-7069

*Nani Maharani, Universitas Diponegoro, Faculty of Medicine, Department of Pharmacology and Therapeutics, Tembalang Semarang Indonesia 50275,

E-mail: maharani.nani@fk.undip.ac.id ORCID: https://orcid.org/0000-0001-5984-6439

Corresponding author: * 